\title{
Lactation traits associated with short- and long-term once-daily milking performance in New Zealand crossbred dairy cattle
}

\author{
S. R. Davis, ${ }^{* 1}$ S.-A. Turner,† V. Obolonkin, ${ }^{*}$ K. Tiplady, ${ }^{*}$ R. J. Spelman, ${ }^{*}$ and C. V. C. Phyn† \\ *Livestock Improvement Corporation, Private Bag 3016, Hamilton 3240, New Zealand \\ †DairyNZ, Private Bag 3221, Hamilton 3240, New Zealand
}

\section{ABSTRACT}

The main objectives of this study were to establish the relative value of milk yields under twice-daily milking (TDM) as a predictor of yield and yield loss under once-daily milking (ODM), and to understand the role of residual milk and udder storage capacity-related traits in regulating yield and yield loss during ODM. A Holstein-Friesian $\times$ Jersey crossbred herd was established over 2 seasons (years), as 2 individual cohorts on the same farm, managed on a pasture-based system over 4 lactations. Short-term (1-wk) ODM studies, with a starting total of 690 cows, were undertaken in midand late-lactation in lactation 2 and in mid-lactation in lactation 3 for each cohort. A 10-wk study of ODM performance began in mid-lactation in lactation 3 , whereas lactation 4 was a full-lactation assessment of ODM. In the short-term studies, milk yield under ODM was well predicted $\left(\mathrm{R}^{2}=0.7\right.$ to 0.8 in 5 of 6 studies $)$ by the daily yield under TDM in the week before ODM. Yield loss $(\mathrm{kg} / \mathrm{d})$ increased with increasing milk yield and with increasing somatic cell count (SCC), although predictions were relatively poor $\left(\mathrm{R}^{2}=0.09\right.$ to 0.30$)$. Yield loss (\%) decreased with increasing TDM yield in 3 of the 6 studies and was positively correlated with SCC during ODM. Nevertheless, ODM yield loss, in absolute or percentage terms, was a poorly repeatable trait in grazing cows. Part of the variation in yield loss percentage $(30 \%)$ was positively associated with residual milk (\%), measured pretrial, during measurement of functional udder capacity in lactation 3. Total production ( $\mathrm{kg}$ of milk) over the full-lactation ODM study in lactation 4 was correlated with total production in the 10-wk trial in lactation $3(\mathrm{r}=0.72$ and 0.63 for cohorts 1 and 2, respectively). Identifying the highest- and lowest-producing $10 \%$ of animals during the full lactation of ODM indicated that poor production was associated with high yields of residual milk (measured in lactation 3) and, conversely, high production

Received October 8, 2014.

Accepted June 1, 2015.

${ }^{1}$ Corresponding author: steve.davis@lic.co.nz was associated with low yields of residual milk, relative to the other $80 \%$ of animals. These same "high" and "low" production groups from lactation 4 had similar differences in performance in the earlier short-term studies and a larger or smaller percentage yield loss associated with the residual milk measurement. Breeding strategies for ODM may benefit, therefore, from greater emphasis on selecting for a low residual milk fraction to optimize milking performance. Nevertheless, the level of milk production under TDM is a strong phenotypic predictor of milk production under ODM.

Key words: milking frequency, residual milk, oncedaily milking, udder capacity

\section{INTRODUCTION}

Dairy producers in pasture-based dairy industries, such as that found in New Zealand, sometimes choose to milk once daily, for all or part of the lactation, to capture the associated lifestyle, capital, and labor efficiencies of this strategy (Davis et al., 1999; Stelwagen et al., 2013). Milking frequency, however, modulates milk synthesis and secretion in many mammalian species, including dairy cows. The effect of milking frequency is mediated by local regulatory mechanisms within the udder that lead to increased milk output with increased milking frequency or decreased output with reduced frequency (Stelwagen, 2001; Collier et al., 2012; Wall and McFadden, 2012; Stelwagen et al., 2013). Hence, once-daily milking (ODM) results in lower milk yields per cow relative to the standard practice of twice-daily milking (TDM).

Understanding the mechanisms through which reduced milking frequency affects milk production is important for the optimization of milking management under ODM, and to establish the potential for genetic improvement of milk production during ODM. Repeatability of the percentage reduction in milk yield following the transition from TDM to ODM is poor within lactations (Carruthers et al., 1993a; Davis et al., 1998), indicating strong environmental influences (along with measurement errors) on the short-term yield loss measured during ODM. Furthermore, the utility of short- 
term (1-2 wk) ODM as a predictor of ODM performance in a full lactation has never been fully evaluated. This is unfortunate because, in physiological terms, the 2 traits are potentially quite different because the loss in milk production with the introduction of ODM has 2 phases. First, there is an acute decline in milk yield until yield stabilizes at a new, lower level. This phase is mostly reversible, at least out to $7 \mathrm{~d}$ of ODM in mid-lactation (Rémond and Pomiès, 2007). Second, there is a chronic effect of ODM on lactational persistency that is associated with an increased rate of loss of secretory tissue relative to TDM, as indicated by reduced total udder capacity after 10 wk of ODM (Carruthers et al., 1993a). In longer-term and full-lactation studies, it is this latter mechanism that is likely to be a significant part of the negative production response to ODM. Indeed, a decrease in lactational persistency and a shortening of lactation length is a characteristic of ODM during a full lactation in some reports (Rémond and Pomies, 2005; Clark et al., 2006; Hickson et al., 2006) although no effect on persistency was seen in a study with well-fed Holstein cows (Rémond et al., 2004). Clarification of the relationships between lactation phenotypes, such as udder capacity, and the milk production response under short- and longer-term ODM may provide insights into strategies that improve cow performance.

Significant variation also exists among cows in their milk production under ODM, which has been attributed, in part, to breed. Jersey cows appear to be more tolerant of ODM than Holstein-Friesian cows because they have a smaller milk production loss during longer-term ODM (Carruthers et al., 1993a; Clark et al., 2006). The French Montbéliarde breed has also been cited as being more tolerant of ODM than Holstein-Friesian cows (Pomiès et al., 2007). Nevertheless, regardless of breed, the need for an ODM-specific breeding program has been questioned if the proportion of the national herd under full-lactation ODM is very small $(\sim 3 \%$ of farms in New Zealand) and the absolute milk yields under ODM are highly correlated, genetically and phenotypically, with those under TDM milking (McPherson et al., 2007). Therefore, the use of traits under TDM to predict the best (and worst) performing animals under ODM requires investigation.

The phenotypic analysis in the current paper was undertaken to examine inter-relationships among short- and long-term ODM yield and yield loss. A major objective was also to establish the relative value of TDM yield as a predictor of yield loss under ODM and the role of milk and udder storage capacity-related traits in regulating yield under ODM.

The data presented below were gathered as phenotypic measures over 3 lactations in 2 cohorts of cows, in a broader study of the genetics associated with pro- duction traits of Holstein-Friesian $\times$ Jersey crossbred cows in New Zealand (Spelman et al., 2001). Analysis of parts of the ODM data set has been reported previously (Davis et al., 2006; Littlejohn et al., 2010).

\section{MATERIALS AND METHODS}

Approval for all sample collection procedures, manipulations and measurements performed on the dairy cows in the trial was granted by the Ruakura Animal Ethics Committee, Hamilton, New Zealand.

For clarity, and in summary, up to 690 dairy cows (managed in 2 cohorts a year apart) were tested on ODM in 3 short-term (7-d) milking trials (lactations 2 and 3), a 10-wk period in mid to late lactation (lactation 3), and a full lactation (lactation 4). Milk yield was measured daily, and milk fat, protein, and lactose contents and SCC measured before and during all trials (see below for specific details). Additional measurements of functional udder capacity (maximum contained milk weight) and residual milk were taken before and after the 10-wk trial.

\section{Animals and Experimental Design}

The herd consisted of a pedigree with a half-sibling, family structure (Spelman et al., 2001) based on $864 \mathrm{~F}_{2}$ Holstein-Friesian $\times$ Jersey crossbred daughters of $6 \mathrm{~F}_{1}$ sires. The $6 \mathrm{~F}_{1}$ bulls were born from planned matings in 1998. The bulls were sired by 3 Jersey bulls and 3 Friesian bulls (mated to Friesian and Jersey dams, respectively) of genetic merit comparable to that of bulls entering the New Zealand progeny test scheme at that time. The establishment and study of this herd has been described previously (Spelman et al., 2001; Berry et al., 2009). Briefly, the herd was formed over 2 seasons (years) from contracted breeding of cows in commercial herds, calving in August 2000 and 2001. The 2 cohorts of animals were studied over 4 lactations following first calving at $2 \mathrm{yr}$ of age. The ODM studies began in lactation 2 (Table 1) when 690 cows were available for study. The cohorts were managed on a single farm under typical New Zealand dairy farming practices, using a seasonal, pasture-based system. Calving for more than $90 \%$ of the cows in the herd was over an 8-wk period in early spring for lactations 2 and 3 and over 10 wk for lactation 4. Cows grazed perennial rye grass and white clover pasture, supplemented as needed with grass silage. Milking was undertaken in a 60-bale rotary parlor normally twice daily, with 10-h and 14-h intervals between milkings. Milk yield $(\mathrm{kg})$ was recorded daily by Westfalia Metatron 21 milk meters (GEA Farm Technologies GmbH, Bönen, Germany). The timing of the ODM challenges and cow 
Table 1. Once-daily milking (ODM) data sets generated during lactations 2, 3, and 4 .

\begin{tabular}{|c|c|c|c|c|c|}
\hline Data set description & Trial & $\mathrm{DIM}^{1}$ & Trial start & \multicolumn{2}{|c|}{ Number of cows } \\
\hline $\begin{array}{l}\text { Short-term ODM }{ }^{3} \text { mid lactation } 2 \\
\text { Short-term ODM late lactation } 2 \\
\text { Short-term ODM mid lactation } 3 \\
\text { Ten-week ODM lactation } 3 \\
\text { Full-lactation ODM lactation } 4^{5} \\
\text { Udder capacity data (lactation } 3)^{6} \\
\text { Udder capacity data for cows completing } \\
\text { lactation } 4^{7}\end{array}$ & $\begin{array}{l}\text { ST-ODM1 } \\
\text { ST-ODM2 } \\
\text { ST-ODM3 } \\
\text { LT10-ODM } \\
\text { Full-ODM } \\
\text { ST-ODM3 and LT10-ODM } \\
\text { Full-ODM }\end{array}$ & $\begin{array}{l}109(18) \\
210(18) \\
160(20) \\
160(20) \\
- \\
150(19)\end{array}$ & $\begin{array}{l}\text { November } \\
\text { February } \\
\text { January } \\
\text { January } \\
\text { July } \\
\text { January } \\
\text { July }\end{array}$ & $\begin{array}{l}300 \\
292 \\
252 \\
252 \\
216 \\
212 \\
170\end{array}$ & $\begin{array}{l}390 \\
376 \\
341 \\
341 \\
305 \\
333 \\
283\end{array}$ \\
\hline $\begin{array}{l}{ }^{1} \text { Mean DIM (SD) for both cohorts at the } \\
{ }^{2} \text { Cohort } 2 \text { studies were undertaken } 12 \text { mo } \\
{ }^{3} \text { Short-term ODM challenges lasted } 7 \mathrm{~d} \text {. } \\
{ }^{4} \text { ST-ODM } 3 \text { represents the first } 7 \mathrm{~d} \text { of the } \\
{ }^{5} \text { Four hundred ninety cows (cohort } 1, \mathrm{n}= \\
{ }^{6} \text { Only } 517 \text { cows with residual milk and ud }\end{array}$ & $\begin{array}{l}\text { each trial. } \\
\text { hort } 1 . \\
\text { DM trial in lactation } 3 \text {. } \\
\text { cohort } 2, \mathrm{n}=288 \text { ) complet } \\
\text { city data completed the } 10-\end{array}$ & $\begin{array}{l}\text { ion } 4 \text { an } \\
\text { ion trial. }\end{array}$ & $\begin{array}{l}\text { ctation } 3 . \\
\text { venty-eight }\end{array}$ & ied off ea & \\
\hline
\end{tabular}

numbers involved are presented in Table 1. Data from cows producing $<5 \mathrm{~kg}$ of milk/d at the start of each trial (fewer than 5 animals in each study) were excluded from the data sets.

\section{Short-Term ODM}

Overall, 3 sets of short-term ODM production data were collected for each cohort (6 data sets in total) to assess their repeatability within and across lactations and the relationship of the short-term ODM response with long-term ODM performance.

In the 2003-2004 season, cohort 1 animals (in lactation 2) were involved in 2 short-term (7-d) challenges to investigate their tolerance to ODM milking; cows were only milked in the morning (24-h milking interval; Table 1). These challenges took place in mid lactation (ST-ODM1) and late lactation (ST-ODM2). Cohort 2 animals were challenged in the same manner, with studies taking place in the 2004-2005 season at similar stages of lactation. A 10-wk ODM challenge was undertaken with each cohort in their third lactations, beginning in mid lactation (January 20). Data generated in the first $7 \mathrm{~d}$ of this study were equivalent to the other short-term ODM studies and used as an additional short-term ODM data set (ST-ODM3).

For calculation of yield loss, TDM daily milk yields were averaged over the $3 \mathrm{~d}$ preceding the ODM challenge for each animal. These values were then compared with the mean ODM milk yields over $3 \mathrm{~d}$ at the end of the 7-d period. Milk yield was recorded daily in all trials, as described above.

Milk composition (fat, CP, and lactose) was determined in ST-ODM studies on the last day of TDM milking with composite p.m./a.m. milk samples, and on the last day of the ODM milking period (d 7 of ODM) by Fourier-transform infrared spectroscopy using a Milkoscan FT120 (Foss Instruments, Hillerød, Denmark). Somatic cell count was determined on these samples using a Fossomatic 5000 cell counter (Foss Instruments).

\section{Ten-Week ODM (Lactation 3)}

Cohort 1 (252 animals) was milked ODM for $10 \mathrm{wk}$ beginning January 20, 2005 (mid lactation), and cohort 2 (341 animals) was milked ODM for $10 \mathrm{wk}$ beginning January 20, 2006 (mid lactation; Table 1). For calculation of yield loss, TDM daily milk yields were averaged over the $3 \mathrm{~d}$ preceding the ODM challenge for each animal, with these values then compared with the mean 3 -d ODM milk yield at the midpoint (35 d) and end of the 10-wk trial period. Milk composition and SCC were determined weekly throughout the trial, as described previously, although only the milk composition data obtained during TDM were used in the analyses presented for the 10-wk trial (Table 6). Total milk production was calculated by summation of daily yields over the 10 -wk period. During the 10 wk of the study, cows were dried off when milk production was below $5 \mathrm{~kg} / \mathrm{d}$ for $>7 \mathrm{~d}$. Cows showing clinical mastitis pretrial were not included in the trial. Data from 15 cows were excluded because of missing data $(n=8)$ or low milk production $(<5 \mathrm{~kg} / \mathrm{d} ; \mathrm{n}=7)$ under TDM.

\section{Full-Lactation ODM}

Cows calving after their third lactation were subjected to ODM for the whole of lactation 4 (Full-ODM) and their milk yield was recorded daily, throughout. 
Milk composition and SCC were measured once every $2 \mathrm{wk}$, as described above. To compare overall milk production, total milk weights produced during the full lactation were computed from accumulated weight calculated by fitting splines over 30 -d periods. Cows were dried off when milk production was below $5 \mathrm{~kg} / \mathrm{d}$ for $>7$ d. Data from 48 cows were excluded. This included animals with a range of health issues/descriptions including persistent mastitis $(\mathrm{n}=24)$, humane culling ( $\mathrm{n}$ $=6)$, disease/illness $(\mathrm{n}=9)$, premature abortions and dystocia $(\mathrm{n}=5)$, and metabolic disorders $(\mathrm{n}=4)$.

Production data were obtained for 521 cows that completed lactation 4 , of which 490 also completed all of the short- and long-term studies in lactations 2 and 3 . Udder capacity and residual milk measures (see below) were available for 453 cows (see Table 1).

\section{Measurement of Functional Udder Capacity in the 10-wk Trial}

Functional udder capacity (a measure of the maximum storage capacity of the udder) was measured, as described by Davis et al. (1998), in a total of 545 cows involved in the 10-wk trial. Briefly, while on TDM, 10 to $12 \mathrm{~d}$ before ODM milking commenced, cows were left unmilked for 36 to $40 \mathrm{~h}$ and then milked out by machine. Within $60 \mathrm{~min}$ of this milking, cows were remilked following injection of 10 IU of oxytocin [Syntocinon, Novartis (NZ) Ltd., Auckland, New Zealand] via the tail vein. Yields at both milkings were recorded and summed to estimate functional udder capacity. The yield obtained with oxytocin is referred to as residual milk in the following text and expressed as either the absolute value ( $\mathrm{kg}$ of milk) or as a percentage of functional udder capacity. Hours-worth of udder capacity, defined as the number of hours taken to fill the udder at a milk secretion rate observed during TDM or ODM, was calculated as udder capacity $(\mathrm{kg})$ divided by the TDM yield $/ 24(\mathrm{~kg} / \mathrm{h})$ or ODM yield $/ 24(\mathrm{~kg} / \mathrm{h})$. A second measurement of udder capacity was made 7 to $10 \mathrm{~d}$ after the 10-wk ODM milking period was completed. Udder capacity measurements were obtained on approximately $90 \%$ of cows in the 10 -wk trial (Table 1 ). Full recovery of milk yield following $48 \mathrm{~h}$ without milk removal in dairy cows occurs within $48 \mathrm{~h}$ of resumption of twice-daily milking (Dalley and Davis, 2006).

\section{Statistical Analysis}

Data sets were analyzed using simple and multiple regressions in JMP (version 8, SAS Institute Inc., Cary, NC) within cohorts and fitting least squares means after adjusting for cohort, when required. The SCC data were $\log _{10}$ transformed before analysis. Arithmetic means are presented unless otherwise stated.

Predictions of short-term ODM yield loss were based on the model: ODM yield loss $=\mathrm{C}+$ TDM yield + ODM SCC, where $\mathrm{C}$ is a constant, TDM yield is kilograms of milk/day averaged over $3 \mathrm{~d}$ immediately before ODM, and ODM SCC is the $\log _{10}$ transformation of SCC in cells $/ \mathrm{mL}$ on the last day of a 7 -d period of ODM. Yield loss was expressed as absolute yield loss $(\mathrm{kg} / \mathrm{d})$ or relative loss as a percentage of TDM yield.

To examine variation within and across lactation, a nested ANOVA (with lactations as groups and lactation stage as sub-groups) was used to perform a variance components analysis and to calculate within and between lactation standard deviations reported for the short-term trials in lactations 2 and 3. Standard deviations were standardized and expressed as coefficients of variation $(\mathrm{CV}$; standard deviation/mean $\times 100)$.

Difference in production characteristics of the poorly persistent group of cows in the 10-wk trial were assessed by ANOVA after adjustment for fixed effects of cohort. Differences among highest and lowest deciles for production within the full lactation data set were assessed by simple ANOVA after adjustment for fixed effect of cohort. Sire effects were evaluated for all traits by ANOVA, after adjustment for fixed effects of cohort.

\section{RESULTS}

\section{Short-Term ODM Performance Within and Across Lactations}

In both the ST-ODM1 and ST-ODM2 challenges, milk yield declined over the first $48 \mathrm{~h}$ of measurements following the onset of ODM (Figure 1). There was evidence of some recovery of yield after the initial decrease in all except 1 study (ST-ODM1, cohort 2; Figure 1c), with yield stabilizing until the end of the 7 -d ODM period (Figure 1). Yields over the final $3 \mathrm{~d}$ of ODM were all lower $(P<0.001$; by simple ANOVA within trial and cohort) than the 3 -d estimate of TDM yield (see Table 2 for summary). In the 5-d period after resumption of TDM, milk yield only returned to pre-ODM levels in 1 of the trials (ST-ODM2 cohort 1; Figure 1b).

Summary statistics for the 3 ST-ODM trials are presented in Table 2 for each cohort. Milk yield loss in 5 of the 6 ODM challenges (by cohort) ranged from 19.5 to $25.1 \%$ of the TDM yield. The percentage yield loss for cohort 1 in late lactation (ST-ODM2) was markedly lower than in the other studies $(12.5 \pm 0.6 \%)$.

The correlations of TDM or ODM milk yield between mid and late lactation in lactation 2 (within cohort) were relatively strong (overall range $\mathrm{r}=0.65-0.69$ ), 

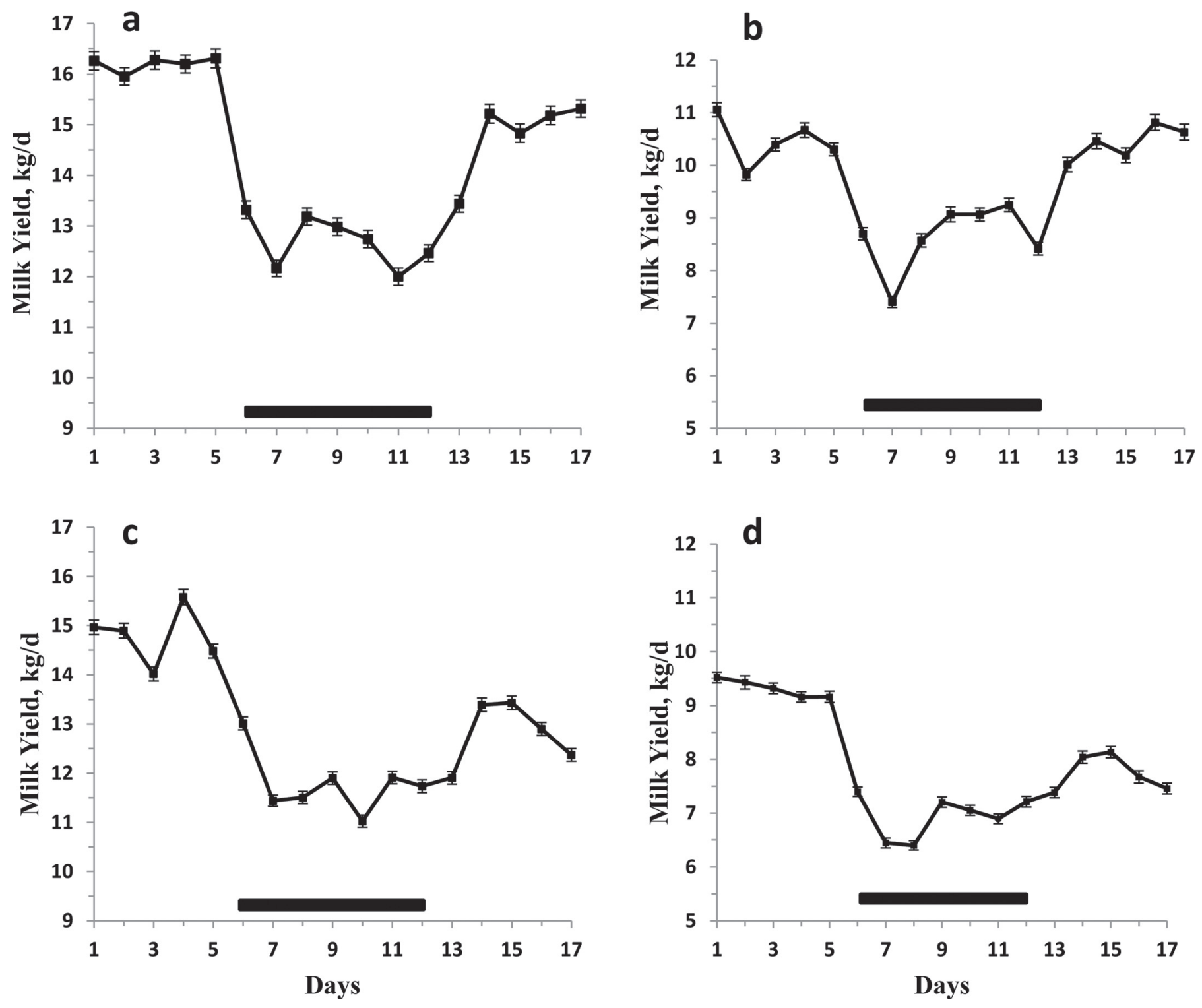

Figure 1. Daily milk yields through the 4 short-term, once-daily milking trials in mid and late lactation (a and b, respectively) for cohort 1 and in mid and late lactation (c and d, respectively) for cohort 2, all in lactation 2. The once-daily milking periods (d 6-12) are indicated by the solid bars. Error bars represent SEM.

as were the correlations across lactations (range $\mathrm{r}=$ 0.51-0.70; Table 3). In contrast, the absolute yield loss $(\mathrm{kg} / \mathrm{d})$ during ODM was poorly correlated (range $\mathrm{r}$ $=0.15-0.20)$ between ST-ODM1and ST-ODM2 trials within the same lactation, and was also poorly correlated across lactations 2 and 3 (range $\mathrm{r}=0.15-0.32$; Table 3). Similarly, the percentage yield loss was poorly correlated between studies within (range $\mathrm{r}=0.19-0.28$ ) and across lactations (range $\mathrm{r}=0.27-0.41$ ). Coefficients of variation for the 4 traits were higher for the loss traits relative to the yield traits, notably when comparing within lactation (Table 4).

\section{Prediction of Short-Term ODM Yield Performance}

The slopes and intercepts of the relationships between milk yield on TDM and ODM in each short-term trial are presented in Table 5. Milk yield of cows under short-term ODM was closely related to their previous TDM performance, with $\mathrm{R}^{2}$ for 5 of the 6 predictions in the range of 0.71 to 0.81 . Slopes of all the relationships were less than unity.

Unlike the daily milk yield on short-term ODM, the yield loss (as $\mathrm{kg} / \mathrm{d}$ or \%) relative to TDM was poorly predicted in all of the studies (Table 6). Short-term loss 
Table 2. Summary statistics (arithmetic means; SEM in parentheses) for the short-term (7 d), once-daily milking (ODM) trials (ST-ODM)

\begin{tabular}{|c|c|c|}
\hline Item & Cohort 1 & Cohort 2 \\
\hline \multicolumn{3}{|l|}{ ST-ODM1 } \\
\hline TDM yield, $\mathrm{kg} / \mathrm{d}$ & $16.3(0.2)$ & $14.8(0.1)$ \\
\hline ODM yield loss, $\mathrm{kg} / \mathrm{d}$ & $3.6(0.1)$ & $3.1(0.1)$ \\
\hline ODM yield loss, \% & $21.9(0.5)$ & $21.0(0.4)$ \\
\hline TDM SCC, $2 \log _{10}$ cells $/ \mathrm{mL}$ & $3.30(0.06)$ & $3.89(0.06)$ \\
\hline ODM SCC, ${ }^{3} \log _{10}$ cells $/ \mathrm{mL}$ & $4.20(0.05)$ & $4.28(0.05)$ \\
\hline \multicolumn{3}{|l|}{ ST-ODM2 } \\
\hline TDM yield, kg/d & $10.5(0.1)$ & $9.2(0.1)$ \\
\hline ODM yield loss, $\mathrm{kg} / \mathrm{d}$ & $1.3(0.1)$ & $2.2(0.1)$ \\
\hline ODM yield loss, \% & $12.5(0.6)$ & $25.0(0.5)$ \\
\hline TDM SCC, $2 \log _{10}$ cells $/ \mathrm{mL}$ & $4.16(0.05)$ & $4.58(0.06)$ \\
\hline ODM SCC, ${ }^{3} \log _{10}$ cells $/ \mathrm{mL}$ & $4.52(0.06)$ & $4.35(0.06)$ \\
\hline \multicolumn{3}{|l|}{ ST-ODM3 } \\
\hline TDM yield, $\mathrm{kg} / \mathrm{d}$ & $15.4(0.2)$ & $14.7(0.1)$ \\
\hline Yield loss, $\mathrm{kg} / \mathrm{d}$ & $3.0(0.1)$ & $3.6(0.1)$ \\
\hline Yield loss, $\%$ & $19.5(0.6)$ & $25.1(0.8)$ \\
\hline TDM SCC,${ }^{2} \log _{10}$ cells $/ \mathrm{mL}$ & $4.26(0.07)$ & $4.62(0.06)$ \\
\hline ODM SCC ${ }^{3} \log _{10}$ cells $/ \mathrm{mL}$ & $4.68(0.08)$ & $4.65(0.07)$ \\
\hline
\end{tabular}

${ }^{1}$ The ST-ODM1 challenge was carried out in mid lactation and STODM2 in late lactation of lactation 2. ST-ODM3 was undertaken in mid lactation 3. The mean yield during twice-daily milking (TDM) was measured over $3 \mathrm{~d}$ immediately before ODM. Yield loss (as \% or $\mathrm{kg} / \mathrm{d}$ ) was measured from the mean milk yield over the last $3 \mathrm{~d}$ of ODM in a 7 -d period.

${ }^{2} \mathrm{SCC}$ determined during TDM on the day immediately before ODM. ${ }^{3} \mathrm{SCC}$ determined during TDM on the last day of ODM.

of milk production $(\mathrm{kg} / \mathrm{d})$ was predicted by a linear model including SCC during ODM and the prior TDM yield ( $\mathrm{kg}$ of milk/d). However, it was not possible to account for more than 25 to $30 \%$ of the variance in absolute yield loss in the ST-ODM1 challenges during mid lactation and even less in ST-ODM2 and ST-ODM3.

Predictions of the percentage loss in milk yield during ODM in each short-term trial with TDM yield and SCC (during ODM) were also relatively weak (Table $6)$. In 5 out of 6 predictions, the TDM yield and percentage loss were negatively related. Further, in 3 data sets (cohorts 1 and 2 for ST-ODM1, and cohort 1 for
ST-ODM2), the effect of TDM yield on the percentage loss was not significant $(P>0.05)$. The SCC during ODM had a significant $(P<0.001)$ effect in all of the predictions. Nevertheless, overall $\mathrm{R}^{2}$ values were low, ranging from 0.06 to 0.19 across the 6 trials (Table 6 ).

The effect of SCC during ODM on absolute and percentage yield loss was significant $(P<0.001)$ in all data sets (Table 6 ). There was a positive association $(\mathrm{r}=0.52$ to $0.81 ; P<0.01)$ between SCC under TDM with that under ODM in all data sets except cohort 1 , ST-ODM2 $(\mathrm{r}=0.0)$. However, the effect of SCC during TDM on absolute yield loss during short-term ODM was only significant $(P<0.01)$ for cohort 1 in STODM1 and ST-ODM3 and for cohort 2 in ST-ODM1 (results not shown).

Milk composition as a predictor of ODM yield loss was also examined with these models. Effects of milk protein, fat, or lactose content (during TDM or ODM) on the prediction of absolute yield loss were small and inconsistent across the trials (data not shown). Overall, inclusion of milk fat, protein, or lactose content during TDM or changes in milk components after transition to ODM did not improve the accuracy of prediction of ODM yield loss in either absolute or percentage terms.

\section{Cow Performance During the 10-wk ODM Trial and Functional Udder Capacity}

Overall, 18 cows (mean TDM yield, pretrial, of 7.9 $\pm 0.7 \mathrm{~kg}$ of milk/d) were dry within $5 \mathrm{wk}$ of beginning ODM, increasing to 48 cows at 10 wk (mean TDM yield of $11.1 \pm 0.4 \mathrm{~kg}$ of milk/d). For the 545 cows that maintained lactation during the LT10-ODM challenge, the rate of decrease in daily milk yield over the 10 -wk period varied substantially among animals. On average, for each cohort, the rate of yield loss was 5.1 to $6.1 \mathrm{~kg}$ of milk/d equivalent, over the 10-wk trial. This was in addition to an acute production loss of $>3 \mathrm{~kg}$ of

Table 3. Correlation coefficients for milk yield traits among the short-term $(7 \mathrm{~d})$, once-daily milking (ODM) studies (ST-ODM) ${ }^{1}$

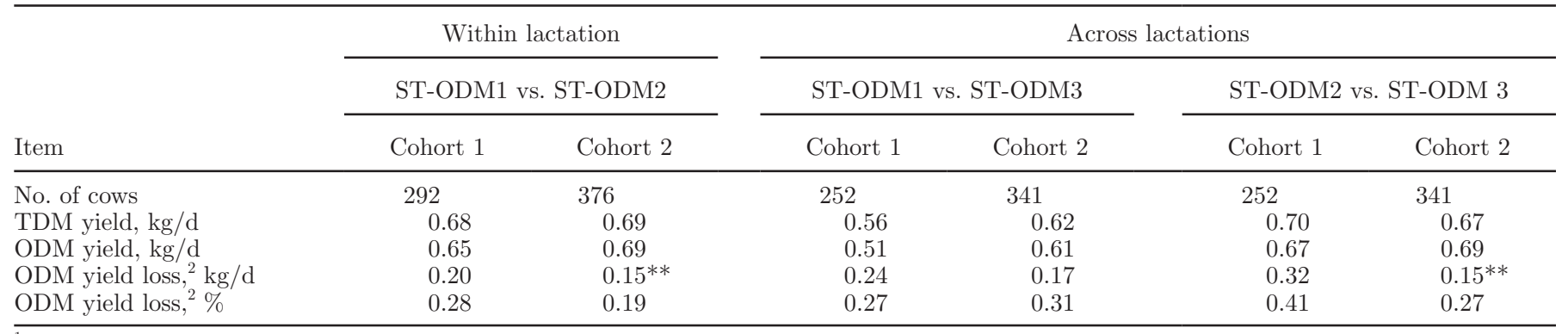

${ }^{1}$ The ST-ODM1 challenge was carried out in mid lactation and the ST-ODM2 challenge in late lactation of lactation 2, whereas ST-ODM3 was undertaken in mid lactation of lactation 3 . The mean yield during twice-daily milking (TDM) was measured over $3 \mathrm{~d}$ immediately before ODM. All correlations were $P<0.001$ except those marked $* *(P<0.01)$ from simple linear regressions within cohort.

${ }^{2}$ Yield loss (as \% or kg/d) was measured from the mean milk yield over the last $3 \mathrm{~d}$ of ODM in a 7-d period. 
DAVIS ET AL.

Table 4. Coefficients of variation (\%; pooled, from nested ANOVA)

\begin{tabular}{lccccc}
\hline & \multicolumn{2}{c}{ Cohort $1(\mathrm{CV} \%)$} & & \multicolumn{2}{c}{ Cohort 2 (CV \%) } \\
\cline { 2 - 3 } \cline { 5 - 6 } Item $^{1}$ & $\begin{array}{c}\text { Within } \\
\text { lactation }\end{array}$ & $\begin{array}{c}\text { Across } \\
\text { lactation }\end{array}$ & & $\begin{array}{c}\text { Within } \\
\text { lactation }\end{array}$ & $\begin{array}{c}\text { Across } \\
\text { lactation }\end{array}$ \\
\hline TDM yield, $\mathrm{kg} / \mathrm{d}$ & 25 & 10 & & 27 & 14 \\
ODM yield, kg/d & 25 & 8 & & 32 & 12 \\
ODM yield loss, kg/d & 61 & 14 & & 52 & 22 \\
ODM yield loss, \% & 57 & 10 & & 47 & 5 \\
\hline
\end{tabular}

${ }^{1} \mathrm{TDM}=$ twice-daily milking; ODM = once-daily milking.

milk/d with the onset of ODM (Table 7 ). The 48 cows that were dried off early had a lower TDM yield, a greater absolute and percentage loss under ODM, and a substantially lower overall milk production compared with the rest of the cows (Table 7).

Mean udder capacity (kg of milk) under TDM was similar in both cohorts at the start of the 10-wk ODM trial but lower in the group of 28 cows $(\mathrm{n}=12$, cohort 1 and $\mathrm{n}=16$, cohort 2) for which udder capacity measures were obtained, that failed to maintain lactation over the 10-wk trial (Table 7). Milk yield under TDM was positively correlated with udder capacity measured at the start of the 10 -wk trial in both cohort $1(\mathrm{r}=$ $0.56, \mathrm{n}=212 ; P<0.001)$ and cohort $2(\mathrm{r}=0.43, \mathrm{n}=$ 333; $P<0.001)$. Residual milk $(\%)$, measured pretrial under TDM, in the 28 cows that were dried off early (and for which residual milk data were available), was 3 -fold greater than the average of the rest of the cows, and udder capacity, calculated as hours-worth of secretion, was also markedly greater in this group (Table 7). In the cows that maintained lactation during the LT10-ODM challenge, udder capacity was reduced by $7.3 \mathrm{~kg}$ of milk, on average, for both cohorts between the $10 \mathrm{~d}$ before and $10 \mathrm{~d}$ after the 10-wk period of ODM. Pretrial residual milk (\%) was positively associated with udder capacity loss (\%) over the 10-wk trial (n = 517 ; accounting for $20 \%$ of the variance) after adjusting for a fixed effect of cohort.
The SCC and milk lactose, fat, and protein contents had no significant effect on the prediction of loss $(\mathrm{kg}$ of milk) in udder capacity (data not shown). The measurements of udder capacity ( $\mathrm{kg}$ of milk) made before and after the 10-wk trial were correlated (cohort $1, \mathrm{r}=$ $0.57 ; P<0.001 ; \mathrm{n}=201$; cohort $2 ; \mathrm{r}=0.35 ; \mathrm{n}=247)$. Similarly, residual milk (\%) was also correlated across the 10 -wk trial $(\mathrm{r}=0.32$ and $\mathrm{r}=0.37$ for cohorts 1 and 2 , respectively, both $P<0.001$ ).

\section{Prediction of Milk Yield and Yield Loss During the 10-wk ODM Trial}

Total production (kg of milk) during the 10-wk ODM study was well predicted by TDM yield ( $\mathrm{kg}$ of milk/d) immediately before the ODM period (cohort $1, \mathrm{R}^{2}=$ $0.67, \mathrm{n}=252$; cohort $2, \mathrm{R}^{2}=0.65, \mathrm{n}=341$ ). Further, this prediction was markedly improved by the inclusion of percentage yield loss in the short-term trial (STODM3) within each cohort $\left(\mathrm{R}^{2}=0.85\right.$ and 0.80 for cohorts 1 and 2, respectively).

Prediction equations for the short-term yield loss $(\mathrm{kg}$ of milk/d and \%) during the first wk of the 10-wk trial (i.e., ST-ODM3) using TDM milk yield and SCC during ODM are presented in Table 6. Addition of residual milk (\%) measured pretrial during TDM to the models in Table 6 for ST-ODM3 that predicted short-term yield loss $\left(\mathrm{kg}\right.$ of milk/d) increased $\mathrm{R}^{2}$ from 0.09 to 0.30

Table 5. Simple linear regression relationships (SEM in parentheses) for once-daily milking (ODM) yield (kg of milk/d) on twice-daily milking (TDM) yield ( $\mathrm{x} ; 1$ wk before ODM) among the short-term (7 d) ODM trials (ST-ODM) within cohort ${ }^{1}$

\begin{tabular}{llcccc}
\hline Cohort & Trial & Intercept & Slope & $\mathrm{R}^{2}$ & RMSE $^{2}$ \\
\hline 1 & ST-ODM1 & $0.49(0.46)$ & $0.75(0.03)$ & 0.71 & 1.22 \\
2 & ST-ODM1 & $0.27(0.30)$ & $0.77(0.02)$ & 0.79 & 0.99 \\
1 & ST-ODM2 & $-0.50(0.29)$ & $0.93(0.03)$ & 0.80 & 0.93 \\
2 & ST-ODM2 & $-0.95(0.20)$ & $0.86(0.02)$ & 0.81 & 0.78 \\
1 & ST-ODM3 & $-1.32(0.48)$ & $0.89(0.03)$ & 0.77 & 1.26 \\
2 & ST-ODM3 & $-0.49(0.53)$ & $0.78(0.04)$ & 0.59 & 1.77 \\
\hline
\end{tabular}

${ }^{1}$ The ST-ODM1 challenge was carried out in mid lactation and ST-ODM2 in late lactation of lactation 2, whereas ST-ODM3 was undertaken in mid lactation of lactation 3. The mean yield during TDM was measured over $3 \mathrm{~d}$ immediately before ODM and the ODM yield calculated as the mean yield over the last $3 \mathrm{~d}$ of the ODM period.

${ }^{2}$ Root mean square error. 
Table 6. Multiple regression relationships (SEM in parentheses) to predict short-term once-daily milking (ODM) yield loss ${ }^{1}$

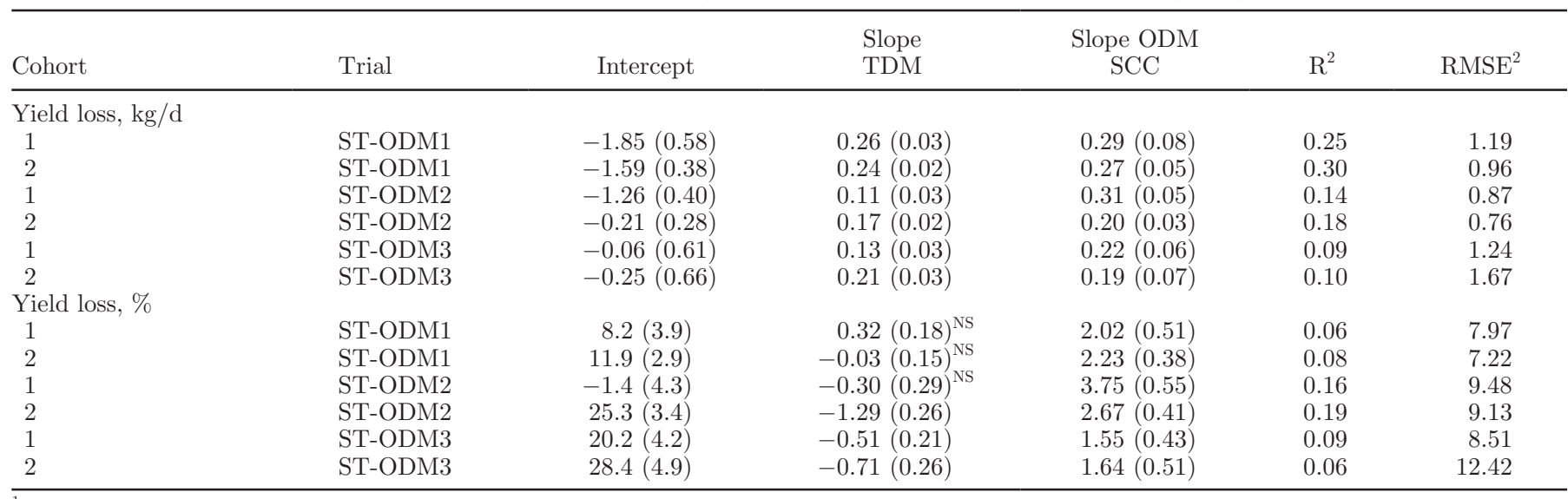

${ }^{1}$ Yield loss was expressed as absolute yield loss (kg/d) or as relative loss [percentage of twice-daily milking (TDM) yield]. The ST-ODM1 challenge was carried out in mid lactation and ST-ODM2 in late lactation of lactation 2, whereas ST-ODM3 was undertaken in mid lactation of lactation 3 .

${ }^{2}$ Root mean square error.

${ }^{\mathrm{NS}} P>0.05$.

and from 0.10 to 0.20 for cohorts 1 and 2 , respectively. Adding the pretrial residual milk (\%) measured during TDM into the model predicting the percentage loss (Table 6) improved $\mathrm{R}^{2}$ from 0.09 to 0.23 and from 0.06 to 0.20 for cohorts 1 and 2 , respectively. Residual milk (\%) alone explained $30 \%$ of the variance in yield loss
(\%) after adjusting for a fixed effect of cohort $\left(\mathrm{R}^{2}=\right.$ $0.30, P<0.001 ; \mathrm{n}=545)$.

Total production in the 10-wk ODM trial was negatively correlated $(P<0.01)$ with the pretrial estimate of residual milk (\%) in both cohort $1(\mathrm{r}=-0.35 ; P<$ 0.001: $\mathrm{n}=212)$ and cohort $2(\mathrm{r}=-0.62 ; P<0.001$;

Table 7. Summary statistics (arithmetic means; SEM in parentheses) for the 10-wk once-daily milking (ODM) trial, by cohort ${ }^{1}$

\begin{tabular}{|c|c|c|c|c|}
\hline Item & $\begin{array}{l}\text { Cohort } 1 \\
(\mathrm{n}=232)\end{array}$ & $\begin{array}{l}\text { Cohort } 2 \\
(\mathrm{n}=313)\end{array}$ & $\begin{array}{c}100 \% \text { loss } \\
(\mathrm{n}=48)\end{array}$ & $\begin{array}{l}\text { Significance } \\
\qquad(P<)\end{array}$ \\
\hline TDM yield, $\mathrm{kg} / \mathrm{d}$ & $15.7(0.2)$ & $15.0(0.1)$ & $11.1(0.4)$ & 0.001 \\
\hline ST-ODM3 yield loss, kg/d & $2.9(0.1)$ & $3.6(0.1)$ & $4.4(0.3)$ & 0.05 \\
\hline ODM yield loss,$^{2} \mathrm{~kg} / \mathrm{d}$ & $6.1(0.1)$ & $5.1(0.10)$ & $6.7(0.4)$ & 0.02 \\
\hline TDM SCC, $\log _{10}$ cells/mL & $4.2(0.1)$ & $4.6(0.1)$ & $4.9(0.2)$ & NS \\
\hline ODM SCC,${ }^{3} \log _{10}$ cells $/ \mathrm{mL}$ & $4.6(0.1)$ & $4.6(0.1)$ & $5.3(0.2)$ & NS \\
\hline TDM milk protein, $\%$ & $4.15(0.02)$ & $3.85(0.01)$ & $4.00(0.04)$ & 0.05 \\
\hline TDM milk lactose, $\%$ & $4.71(0.01)$ & $4.67(0.01)$ & $4.51(0.03)$ & 0.001 \\
\hline Udder capacity start, $\mathrm{kg}$ of milk & $18.3(0.2)$ & $17.5(0.2)$ & $15.7(0.6)$ & 0.001 \\
\hline Udder capacity loss, kg of milk & $7.8(0.2)$ & $6.8(0.2)$ & Not determined & \\
\hline Residual milk, ${ }^{5} \%$ & $11.0(1.0)$ & $14.3(0.7)$ & $39.2(3.2)$ & 0.001 \\
\hline Udder capacity, ${ }^{6}$ hours-worth TDM & $28.0(0.3)$ & $28.3(0.4)$ & $38.0(1.6)$ & 0.001 \\
\hline Udder capacity, ${ }^{6}$ hours-worth ODM & $34.3(0.4)$ & $38.0(0.7)$ & $77.1(7.6)$ & 0.001 \\
\hline
\end{tabular}

${ }^{1}$ Forty-eight cows were dried off (because of low daily milk yields) before the end of the 10-wk trial (mean trial DIM $45 \pm 10$ ) and these data are presented separately (100\% loss column). Data were pooled for cohorts $1(\mathrm{n}=20)$ and $2(\mathrm{n}=28)$ for this group. Udder capacity and residual milk data were obtained for 28 of the 48 animals in the $100 \%$ loss group and a further 517 animals in cohorts 1 ( $\mathrm{n}=200)$ and 2 (n $=317$; total $\mathrm{n}=545$, see Table 1 ). The $100 \%$ loss group was contrasted with remaining animals by ANOVA after adjusting for cohort. TDM $=$ twice-daily milking; ST-ODM3 = short-term ODM (i.e., wk 1 of the 10-wk trial in lactation 3).

${ }^{2}$ Yield loss from wk 1 to 10 during ODM. Total reduction in daily yield over the trial is the sum of ST-ODM loss and ODM yield loss.

${ }^{3}$ Somatic cells measured on d 7 of ODM.

${ }^{4}$ Milk composition during TDM, immediately before ODM commenced.

${ }^{5}$ Measured pretrial during TDM.

${ }^{6}$ Udder capacity (measured pretrial) calculated as capacity ( $\mathrm{kg}$ of milk) divided by hourly milk yield calculated for pretrial TDM or hourly milk yield after the first week of ODM. 
Table 8. Production characteristics (least squares means; SEM in parentheses, after adjusting for cohort) of cows ${ }^{1}$ in highest and lowest deciles for total production under full-lactation, once-daily milking (ODM) in lactation 4, and their performance in earlier ODM trials

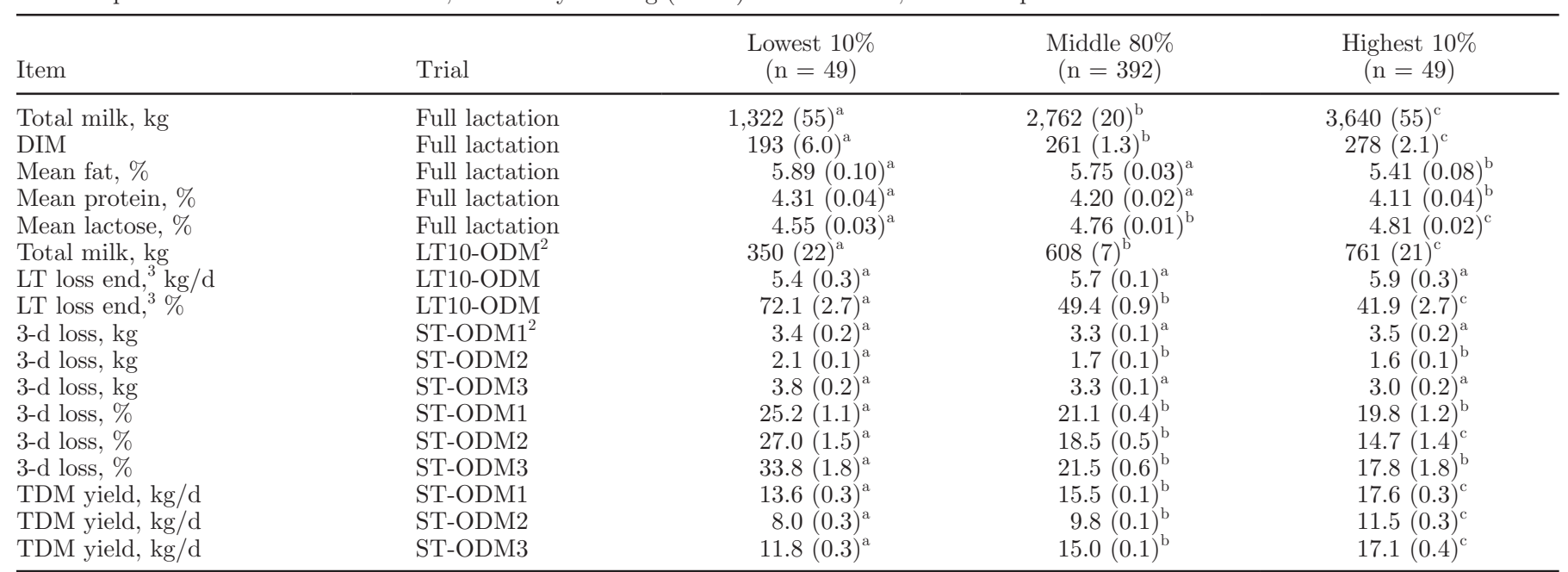

${ }^{a-c}$ Data with differing superscripts within rows were significantly different by ANOVA $(P<0.05)$, including cohort and decile category in the model.

${ }^{1} \mathrm{n}=490$ for cows that had data available for all of the short-term and long-term studies. Data set included 40 cows that failed to complete the 10-wk trial. Twenty of these cows were in the lowest decile and 20 in the middle group for lactation 4.

${ }^{2} \mathrm{LT}=$ long-term. LT10-ODM was a 10-wk ODM trial starting in mid lactation during lactation 3, and ST-ODM1, 2, and 3 were all short-term (7-d) ODM studies. See Table 1.

${ }^{3}$ Long-term loss was calculated as the difference between ODM milk yield at the start and end of the 10-wk trial, as absolute loss (kg/d) or as a $\%$ of the ODM yield in wk 1 .

$\mathrm{n}=333)$. Pretrial TDM yield was also negatively correlated with residual milk percentage $(\mathrm{r}=-0.20 ; P<$ $0.01 ; \mathrm{n}=212 ; \mathrm{r}=-0.47 ; P<0.001 ; \mathrm{n}=333)$.

Udder capacity ( $\mathrm{kg}$ of milk; pretrial) was correlated $(P<0.001)$ with total 10 -wk production $($ ODM $)$ for cohort $1(\mathrm{r}=0.33)$ and cohort $2(\mathrm{r}=0.48)$. Expressing udder capacity as hours-worth of secretion using pretrial TDM or ODM milk yield in wk 1 explained only $5 \%$ of the variation in short-term milk yield loss under ODM and was not significantly correlated with the long-term loss. However, hours-worth of udder capacity was negatively related to total milk production during 10 wk of ODM $(\mathrm{r}=-0.21, P<0.002 ; \mathrm{n}=212$; $\mathrm{r}=-0.46 P<0.001 ; \mathrm{n}=333)$, largely associated with a negative correlation with pretrial TDM yield. Thus, cows with greater hours-worth of udder capacity were also lower producers.

\section{Prediction of Full-Lactation ODM Performance}

The mean total milk produced in the Full-ODM study was $>2,700 \mathrm{~kg}$ from, on average, $255 \pm 1.6 \mathrm{DIM}$ (Table 8 ). The total milk produced under ODM in lactation 4 was correlated with total milk weight produced in the 10-wk ODM trial in lactation 3 (cohort $1 ; \mathrm{r}=$ $0.72, \mathrm{n}=202$, cohort $2 ; \mathrm{r}=0.63, \mathrm{n}=288, P<0.001$ ). Furthermore, these correlations increased to $\mathrm{r}=0.84$ and 0.77 (for cohorts 1 and 2, respectively) when total milk produced in lactation 4 was adjusted for lactation length. The measurement of residual milk (\%) made before the 10-wk ODM trial in lactation 3 was also

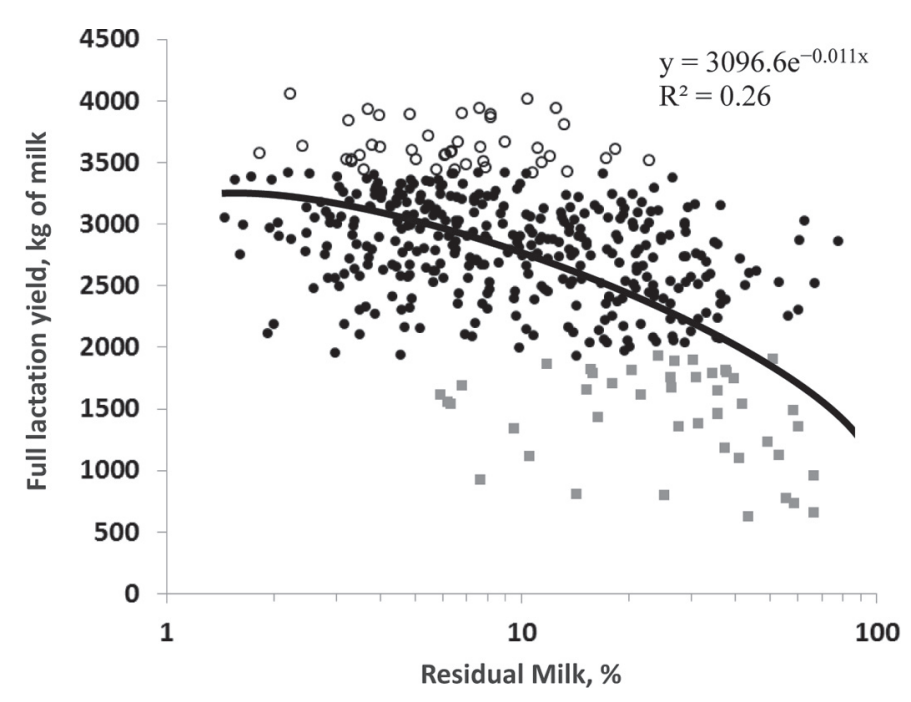

Figure 2. The relationship between milk yield in a full lactation of once-daily milking in lactation 4 and a measurement of residual milk (\%; made during twice-daily milking in the middle of lactation $3, \mathrm{n}=453)$. Production data have been adjusted for difference between cohorts and residual milk (\%) $\log _{10}$ transformed to normalize. Top (white circles) and bottom (gray squares) deciles and middle $80 \%$ (black circles) for production in lactation 4 are shown. 
Table 9. Udder capacity and related measures (least squares means; SEM in parentheses) for cows ranked by once-daily milking (ODM) production during lactation 4 into highest and lowest deciles ${ }^{1}$

\begin{tabular}{lccc}
\hline Item & $\begin{array}{c}\text { Lowest } 10 \% \\
(\mathrm{n}=46)\end{array}$ & $\begin{array}{c}\text { Middle 80\% } \\
(\mathrm{n}=361)\end{array}$ & $\begin{array}{c}\text { Highest 10\% } \\
(\mathrm{n}=46)\end{array}$ \\
\hline Udder capacity, kg & $16.2(0.5)^{\mathrm{a}}$ & $17.6(0.2)^{\mathrm{b}}$ & $19.2(0.5)^{\mathrm{c}}$ \\
Udder capacity loss, kg & $8.2(0.6)^{\mathrm{a}}$ & $7.2(0.2)^{\mathrm{ab}}$ & $6.2(0.5)^{\mathrm{b}}$ \\
Udder capacity loss, \% & $45(3)^{\mathrm{a}}$ & $40(1)^{\mathrm{a}}$ & $32(2)^{\mathrm{b}}$ \\
Udder capacity, hours-worth & $32.2(1.0)^{\mathrm{a}}$ & $28.0(0.3)^{\mathrm{b}}$ & $27.0(1.0)^{\mathrm{b}}$ \\
ST-ODM3 TDM yield, kg/d & $12.5(0.3)^{\mathrm{a}}$ & $15.2(0.1)^{\mathrm{b}}$ & $17.2(0.3)^{\mathrm{c}}$ \\
ST-ODM3 ${ }^{2}$ yield loss, \% & $32.1(1.5)^{\mathrm{a}}$ & $21.4(0.6)^{\mathrm{b}}$ & $17.7(1.5)^{\mathrm{c}}$ \\
Residual milk, kg & $4.8(0.4)^{\mathrm{a}}$ & $2.3(0.1)^{\mathrm{b}}$ & $1.5(0.4)^{\mathrm{b}}$ \\
Residual milk, \% & $28.9(1.8)^{\mathrm{a}}$ & $12.6(0.7)^{\mathrm{b}}$ & $7.7(1.8)^{\mathrm{c}}$ \\
Residual milk, \%, post-ODM & $15.1(2.1)^{\mathrm{a}}$ & $10.3(0.6)^{\mathrm{b}}$ & $7.7(1.7)^{\mathrm{b}}$ \\
LT10-ODM, total milk, kg & $424(21)^{\mathrm{a}}$ & $624(8)^{\mathrm{b}}$ & $763(21)^{\mathrm{c}}$ \\
Full lactation, total milk, kg & $1,533(57)^{\mathrm{a}}$ & $2,797(21)^{\mathrm{b}}$ & $3,626(57)^{\mathrm{c}}$ \\
\hline
\end{tabular}

${ }^{a-c}$ Data with differing superscripts within rows were significantly different by ANOVA $(P<0.05)$, after adjusting for fixed effect of cohort.

${ }^{1}$ Udder capacity measures were made in lactation 3 along with residual milk determinations before and after 10 wk of ODM. Fourteen of 100\% loss cows in LT-10 ODM were in the lowest decile and 12 were in middle group.

${ }^{2}$ The ST-ODM3 challenge was the short-term $(7 \mathrm{~d})$ ODM data set at the start of the 10-wk ODM trial (LT10ODM) beginning in mid lactation 3 . The mean yield during twice-daily milking (TDM) was measured over 3 d immediately before ODM.

negatively correlated with Full-ODM performance ( $\mathrm{r}=$ $-0.51, P<0.001 ; \mathrm{n}=453$; Figure 2).

Production characteristics of the lowest and highest decile producers in the Full-ODM study are presented in Table 8 and compared with the performance traits of the same animals in the earlier trials. Generally, the lowest producers in lactation 4 were also lower producers under TDM and had greater percentage yield losses in all the short-term and 10-wk ODM trials. However, there were only small differences in absolute ODM yield loss ( $\mathrm{kg}$ of milk) in short-term studies among the categories (highest and lowest $10 \%$ and middle $80 \%$ milk producers; Table 8). The yield categories in lactation 4 had similar rankings for total milk produced in the 10-wk ODM trial in lactation 3 (Table 8) and in similar relative proportions.

We found small differences in milk composition between the categories, with the most notable difference being lower lactose percentage in the lowest-yielding group under Full-ODM (Table 8). Further, the highestyielding group was associated with lower milk fat and protein contents but greater lactose content (Table 8).

The smaller data set for cows in lactation 4 that had udder capacity measurements from lactation 3 provided additional traits, characteristic of low and high producers under Full-ODM (Table 9). Udder capacity ( $\mathrm{kg}$ of milk, pretrial in lactation 3) was lowest in the lowest-producing animals in lactation 4 and was significantly higher $(P<0.05)$ in the highest-producing decile. The short-term ODM yield loss (\%) in lactation 3 was greatest in the lowest $10 \%$ of producers identified in lactation 4 , and the loss was compounded by an increased loss of udder capacity over the 10-wk trial. This loss was associated with markedly greater residual milk under TDM in this group, in absolute as well as percentage terms. Further, residual milk (\%) was lower in the top $10 \%$ of producers relative to the "middle" $80 \%$. In summary, cows that were the poorest performers under Full-ODM in lactation 4 had lower milk yields on TDM in the 10-wk trial, a greater yield loss (\%) during short-term ODM, and a greater loss of udder capacity (\% and $\mathrm{kg}$ ) over the 10 -wk ODM trial (Table 9). All of the above results were in association with a greater absolute residual milk yield and residual milk percentage. The converse applied to the $10 \%$ highest producers.

\section{Sire Differences}

We detected differences among the sire daughters in ODM performance (Table 10). Sire 1 and sire 6 were the highest and lowest milk producers, respectively, in both the 10 -wk and full-lactation trials. Sire 6 ranked lowest for volume breeding value, milk yield on ODM and also on TDM, in association with the highest percentage of residual milk. Conversely, sire 1 had the highest volume breeding value and the highest production on TDM and ODM in association with the lowest percentage of residual milk.

Milk yield ranked similarly during twice-daily periods before ST-ODM1. Of interest is that the ranking of sires for milk production was negatively correlated with the level of residual milk (\%) determined in lactation 3. Further, the percentage milk loss over the 10-wk trial and the percentage loss in short-term trial (ST-ODM3) also differed between the highest and lowest produc- 
Table 10. Differences among sires in milk yield during lactation 4 (Full-ODM), once-daily milking (ODM) in lactation 3 (LT-10) for 10 wk, and during twice-daily milking (TDM) before the short-term ODM trial in mid lactation $3^{1}$

\begin{tabular}{|c|c|c|c|c|c|c|}
\hline $\begin{array}{l}\text { Sire } \\
(\text { volume BV; no. })^{2}\end{array}$ & $\begin{array}{l}\text { Full-ODM } \\
\text { yield, kg } \\
\text { of milk }\end{array}$ & $\begin{array}{l}\text { LT10-ODM } \\
\text { yield, kg } \\
\text { of milk }\end{array}$ & $\begin{array}{l}\text { Residual } \\
\text { milk, }{ }^{3} \%\end{array}$ & $\begin{array}{c}\text { ST-ODM3 } \\
\text { TDM yield, } \\
\text { kg/d }\end{array}$ & $\begin{array}{l}\% \text { milk loss } \\
\text { in LT10- } \\
\text { ODM }^{4}\end{array}$ & $\begin{array}{l}\text { 3-d loss \% } \\
\text { ST-ODM3 }\end{array}$ \\
\hline $1(-120 ; 72)$ & $2,917(72)^{\mathrm{a}}$ & $699(18)^{\mathrm{a}}$ & $10.0(1.5)^{\mathrm{b}}$ & $16.1(0.3)^{\mathrm{a}}$ & $43(2)^{\mathrm{c}}$ & $19.1(1.5)^{\mathrm{c}}$ \\
\hline $3(-513 ; 63)$ & $2,755(77)^{\mathrm{ab}}$ & $610(19)^{\mathrm{b}}$ & $11.5(1.6)^{\mathrm{b}}$ & $15.0(0.3)^{\mathrm{b}}$ & $53(2)^{\mathrm{a}}$ & $19.6(1.6)^{\mathrm{bc}}$ \\
\hline $4(-450 ; 88)$ & $2,739(65)^{\mathrm{ab}}$ & $607(16)^{\mathrm{b}}$ & $13.0(1.3)^{\mathrm{b}}$ & $15.4(0.3)^{\mathrm{b}}$ & $50(2)^{\mathrm{ab}}$ & $22.0(1.3)^{\mathrm{abc}}$ \\
\hline $5(-646 ; 70)$ & $2,769(74)^{\mathrm{ab}}$ & $626(19)^{\mathrm{b}}$ & $17.5(1.5)^{\mathrm{a}}$ & $15.1(0.3)^{\mathrm{b}}$ & $46(2)^{b c}$ & $23.3(1.5)^{\mathrm{ab}}$ \\
\hline
\end{tabular}

${ }^{a-c}$ Data with differing superscripts within columns were significantly different by ANOVA $(P<0.05)$, after adjusting for fixed effect of cohort.

${ }^{1}$ Values are least squares means \pm SEM after adjusting for cohort, with sires ordered by residual milk $(\%)$.

${ }^{2}$ Breeding value (BV; relative to a year 2000 base) for volume (L) and number of daughters contributing data.

${ }^{3}$ From pretrial lactation 3 .

${ }^{4}$ Yield loss over LT-10 as a percentage of mean ODM yield over 5 to $7 \mathrm{~d}$.

${ }^{5}$ Yield loss (\%) in ST-ODM3.

ers. Breeding values for volume were greatest (least negative) for the highest-producing sire and least for the lowest-producing sire. Sire explained $4.9 \%$ of the phenotypic variance for full-lactation milk yield, $22 \%$ of the variance for 10 -wk trial production, and $13 \%$ of the phenotypic variance for residual milk percentage. Sire accounted for only 1 and 3\%, respectively, of the phenotypic variance for long-term and short-term loss of milk (\%) during the 10 -wk trial.

\section{DISCUSSION}

\section{The Predictive Value of TDM Yield}

Milk yield under TDM had the greatest predictive value for ODM milk yield, irrespective of the timing or duration of ODM. This trait accounted for a major part of the variance in ODM yield in the short-term studies; in the 10-wk ODM trial, TDM milk yield accounted for over two-thirds of the variance in total production on ODM. Furthermore, the highest producers under fulllactation ODM also had the highest TDM milk yield measured during mid or late lactation in the previous 2 seasons, and vice versa for the lowest producers. These relationships for grazing cows are consistent, therefore, with that reported previously between prior TDM yield and the milk yield during 3 wk of ODM in earlylactating, housed cows (Guinard-Flament et al., 2011). Similarly, a greater TDM yield was also associated with a greater milk yield loss $(\mathrm{kg} / \mathrm{d})$ under ODM, although this relationship was weaker than reported previously for housed cows (Rémond and Pomiès, 2005; GuinardFlament et al., 2011). The percentage loss under ODM, however, is poorly and inconsistently predicted by TDM yield across current and earlier studies (Rémond and
Pomiès, 2005; Guinard-Flament et al., 2011). Hence, milk yield under TDM can be used to predict absolute milk yield under both short- and long-term ODM but this trait does not explain a large proportion of the variance in ODM yield loss (at least in grazing cows).

\section{The Effect of Residual Milk on ODM Performance}

The percentage of residual milk (sometimes known as complementary milk) left in the mammary gland after milking was consistently negatively associated with cow performance under TDM and ODM. Furthermore, the relationship held between lactations as the first measurement of residual milk made pretrial under TDM in lactation 3 was sufficient to distinguish large differences for residual milk (\%) between the high and low decile groups for full-lactation ODM production in lactation 4 . The regression of ODM yield in the full-lactation trial on residual milk (\%) gave a negative correlation between the parameters $(\mathrm{r}=-0.51)$, similar to that reported previously (Carruthers et al., 1993a). Pretrial (under TDM) residual milk (\%) was also much greater in the group of cows that were dried off before the end of the 10-wk ODM trial. Residual milk (\%) was less well correlated with TDM yield than with ODM performance, at least at the start of the 10 -wk trial. Nevertheless, some of the variance seen in TDM yield was likely due to residual milk percentage. In many cases, lower yields in mid-season were likely to have been caused by elevated residual milk (inefficient removal of alveolar milk). Imposition of ODM in such cases would be expected to accelerate the rate of decline in milk production. Thus, the variance attributable to TDM yield and residual milk proportion is most likely confounded. Nevertheless, the conclusion to be drawn from the data is that a high level of residual milk 
before ODM plays a significant, negative role in ODM performance as well as TDM performance.

Support for the importance of residual milk to productivity of cows on ODM comes from the demonstration that supplementary oxytocin injection enhanced milk removal, minimized residual milk, and halved the yield loss under ODM (Carruthers et al., 1993b). Furthermore, cows with "better draining" alveoli (lower residual milk) between milkings had lower losses in milk production under ODM (Davis et al., 1998), whereas removal of cisternal milk during ODM did not enhance production (Farr et al., 1997). The residual milk fraction that is retained in the alveoli (as opposed to strippings from the cistern) is likely to be the crucial measure because of the effect on the degree and duration of negative feedback on milk production via alveolar distension (Davis et al., 1999) or autocrine inhibitors such as serotonin (Collier et al., 2012). Residual milk is a heritable trait $\left(\mathrm{h}^{2}=0.34\right)$ that is highly repeatable across lactations (Kashyap et al., 1967), and it has been correlated elsewhere with yield loss (persistency) under TDM as well as with yield loss with ODM (Turner, 1955; Carruthers et al., 1993a). Thus, although residual milk was associated with poor lactation persistency and lower milk yields in earlier studies with TDM (Turner, 1955; Elliott, 1960), it might be expected that genetic improvements over 40 to $50 \mathrm{yr}$ will have reduced the overall prevalence of "high residual milk" animals. Further work is needed to more accurately define the impact of the efficiency of milk removal on milk yield and persistency under ODM.

\section{The Effect of SCC and Milk Composition on ODM Performance}

The SCC during ODM also had a consistent, albeit small, effect on yield loss in all of the short-term trials. The addition of SCC into the simple prediction models using prior TDM yield indicated that SCC during ODM was positively associated with absolute and percentage yield loss on short-term ODM. However, the proportion of variance explained by SCC was relatively small $(<3 \%)$. In contrast, SCC during TDM had a significant association with short-term ODM yield loss in only half of the data sets. The implication is that SCC during ODM has a negative effect on milk production and that SCC during ODM is correlated with SCC on TDM, which occurred in most of the short-term studies. Indeed, Kamote et al. (1994) compared 2 groups of cows with differing SCC $\left(2.7 \times 10^{5}\right.$ vs. $1.0 \times 10^{6}$ cells/ $\mathrm{mL})$ and reported a greater reduction in milk yield (3.6 vs. $2.0 \mathrm{~kg}$ ) over $4 \mathrm{wk}$ on ODM in the group of cows with high SCC. Once-daily milking is associated with increased neutrophil numbers in milk (Stelwagen and
Lacy-Hulbert, 1996), which may be the driver of the production response to SCC during ODM.

Milk fat, protein, and lactose contents explained only a small part $(3 \%)$ of the variance in milk yield and yield loss (expressed in either absolute or percentage terms), and, in addition, the effects were inconsistent among trials. Overall, the milk composition phenotypes added little to the prediction of ODM performance.

\section{Repeatability of Yield Loss Between ODM Studies}

Short-term yield loss (as $\mathrm{kg} / \mathrm{d}$ and as a percentage of TDM yield) was poorly repeatable between ODM studies. Low correlations for yield loss $(\mathrm{kg} / \mathrm{d})$ of $\mathrm{r}=$ 0.16 to 0.20 were evident within and across lactations, similar to data reported in earlier studies with cows at pasture (Carruthers et al., 1993a). However, these data contrast with those of Rémond and Pomiès (2007), who reported a high correlation of yield loss with ODM at differing stages of lactation in concentrate-supplemented cows. The number of animals they studied, however, was small $(\mathrm{n}=9)$, especially in comparison with the current study, which may explain the different result. Nevertheless, another explanation is that the variation among studies in the repeatability of ODM yield loss (absolute and percentage) may be caused by differences in feeding conditions.

Negative, additive effects of ODM and under-nutrition on milk production have been reported, although the data indicate that when intake is restricted, cows sometimes have a smaller percentage loss in milk production following transition from TDM to ODM (Auldist and Prosser, 1998; Kay et al., 2013). In the current study, there was a markedly smaller percentage loss in production (12.4\%) in cohort 1 in late lactation during ST-ODM2 relative to the other ST-ODM challenges. A similarly low percentage loss was reported for cows in early lactation when pasture intake was restricted (Kay et al., 2013), and in other short-term studies (Carruthers et al., 1993a; Davis et al., 1998) performed in late lactation, which corresponds to a period of lower pasture quality and quantity in seasonal dairy systems in New Zealand. Thus, repeatability of yield loss in grazing cows may be compromised by daily ME intakes being more variable than those of concentrate-fed, housed cows. Greater day-to-day variation in milk yield during grazing will magnify errors in estimation of short-term yield loss because the measure is a difference between TDM and ODM yields. Overall, published data and the data reported here indicate that day-to-day variation in nutritional status will have a significant effect on the measurement of loss of milk production under ODM, and, in particular, on the percentage loss. 


\section{The Role of Udder Capacity in Milk Production on ODM}

In contrast to previous work (Carruthers et al., 1993a; Davis et al., 1998), udder capacity measurements in the current study were not strong predictors of short- or long-term yield loss under ODM. Cows with greater absolute udder capacity (kg of milk) were better producers on TDM and, therefore, also on ODM. However, cows with greater hours-worth of capacity to accumulate secretion were generally lower producers. The difference from previous work likely relates to the larger data set and the use of cross-bred animals. Previously, association of udder capacity and ODM performance was made across breeds (Davis et al., 1999), which potentially confounded the association. A similar magnitude of loss of udder capacity through late lactation in grazing animals has been noted previously. This loss is much greater than that observed in cows fed TMR (Davis et al., 2000). At the milk secretion rates measured in the current studies, udders had the ability to accumulate secretion for $>27 \mathrm{~h}$ under TDM and $36 \mathrm{~h}$ under ODM, indicating that udder capacity, per se, was not a primary physical constraint to ODM performance, at least in crossbred, grazing animals. In "high-volume" breeds, such as the American Holstein, udder capacity may remain a primary constraint to production under ODM (Davis et al., 1999), especially when managed in high-input feeding systems.

\section{The Predictive Value of Cow Phenotypes Under Short-Term and Part-Season ODM for Full-Lactation ODM Performance}

Cow performance under full-lactation ODM was related to their responses in the short-term and 10-wk ODM studies. Production in the full-lactation ODM trial was well predicted by production in the 10-wk study during the previous lactation. Furthermore, animals in the high and low deciles for production also had lower and higher percentage losses, respectively, during ODM in lactation 3 , in both short-term studies and the 10-wk trial. The differential was slightly reduced in the first 2 short-term studies in lactation 2, although differences remained. Thus, although short-term ODM yield loss was, itself, a poorly repeatable trait, there was some consistency in the extremes of ODM performance across lactations, indicating that high or low performance for groups of animals in short-term or part-season ODM could predict their performance under full-lactation ODM. Production loss data (expressing ODM milk yield response as absolute or percentage loss) were inferior to TDM milk yield as predictors of ODM performance. Nevertheless, such data could be used with TDM yield to increase the accuracy of prediction of performance under ODM.

\section{CONCLUSIONS}

The data from the full-lactation ODM study indicate that performance of cows on ODM is well predicted by TDM production, but the latter does not explain all of the variation among cows. Indeed, among all the cows that were studied, the best producers on ODM were cows with a high TDM yield and a low level of residual milk. Of note was the consistent ranking among sires for production in the long-term trials and the association of ranking with residual milk percentage. Sensitivity of milk production to SCC may also be increased under ODM but more data are needed to support this contention. Published data and data presented herein indicate that yield losses on ODM will be lower in unsupplemented, grazing cows, where volume production is nutritionally restricted, although more clarity is needed around the interaction of nutrition and yield loss on ODM. The question has been posed as to whether it is possible to specifically breed a cow suited to ODM (McPherson et al., 2007). To maximize production, the ODM cow should have high genetic merit for milk production under TDM. Furthermore, low residual milk fraction (and possibly low SCC) is likely to be a more important trait associated with milk production on ODM, relative to the effect of residual milk during TDM. Breeding strategies for ODM may be improved by placing greater emphasis on minimizing residual milk to optimize lactation performance.

\section{ACKNOWLEDGMENTS}

Authors are grateful to staff at DairyNZ (Hamilton, New Zealand) and the Whareroa Fonterra farm (Hawera, Taranaki) for farm management, technical expertise, and sampling assistance. This research was funded by the Fonterra Co-operative Group (Auckland, New Zealand), Livestock Improvement Corporation (Hamilton, New Zealand), New Zealand Ministry for Business, Innovation and Employment (Wellington, New Zealand), and by New Zealand dairy farmers through DairyNZ Inc. (Hamilton, New Zealand).

\section{REFERENCES}

Auldist, M. J., and C. G. Prosser. 1998. Differential effects of shortterm once-daily milking on milk yield, milk composition and concentrations of selected blood metabolites in cows with low or high pasture intake. Proc. N.Z. Soc. Anim. Prod. 58:41-43.

Berry, S. D., S. R. Davis, E. M. Beattie, N. L. Thomas, A. K. Burrett, H. E. Ward, A. M. Stanfield, M. Biswas, A. E. Ankersmit-Udy, P. E. Oxley, J. L. Barnett, J. F. Pearson, Y. van der Does, A. H. K. MacGibbon, R. J. Spelman, K. Lehnert, and R. G. Snell. 2009. 
Mutation in bovine beta-carotene oxygenase 2 affects milk color. Genetics 182:923-926.

Carruthers, V. R., S. R. Davis, A. M. Bryant, H. V. Henderson, C. A. Morris, and P. J. A. Copeman. 1993a. Response of Jersey and Friesian cows to once a day milking and prediction of response based on udder characteristics and milk composition. J. Dairy Res. 60:1-11.

Carruthers, V. R., S. R. Davis, and P. J. A. Copeman. 1993b. Effects of oxytocin, machine stripping and milking rate on production loss of cows milked once a day. J. Dairy Res. 60:13-18.

Clark, D. A., C. V. C. Phyn, M. J. Tong, S. J. Collis, and D. E. Dalley. 2006. A systems comparison of once- versus twice-daily milking of pastured dairy cows. J. Dairy Sci. 89:1854-1862.

Collier, R. J., L. L. Hernandez, and N. D. Horseman. 2012. Serotonin as a homeostatic regulator of lactation. Domest. Anim. Endocrinol. 43:161-170.

Dalley, D. E., and S. R. Davis. 2006. Effect of an extended milking interval on recovery of milk yield and somatic cell count in dairy cows. Proc. N.Z. Soc. Anim. Prod. 66:241-244.

Davis, S., L. McNaughton, G. Bracefield, K. Sanders, and R. Spelman. 2006. Variation in milk yield response to once-daily milking in Friesian-Jersey crossbred cattle. J. Dairy Sci. 89(Suppl. 1):146-147.

Davis, S. R., V. C. Farr, M. J. Auldist, and E. S. Kolver. 2000. Effects of diet on udder function and regression in Holstein-Friesian cattle. Proc. N.Z. Soc. Anim. Prod. 60:275-276.

Davis, S. R., V. C. Farr, P. J. A. Copeman, V. R. Carruthers, C. H Knight, and K. Stelwagen. 1998. Partitioning of milk accumulation between cisternal and alveolar compartments of the bovine udder: relationship to production loss on once-daily milking. J. Dairy Res. 65:1-8.

Davis, S. R., V. C. Farr, and K. Stelwagen. 1999. Regulation of yield loss and milk composition during once-daily milking: A review. Livest. Prod. Sci. 59:77-94.

Elliott, G. 1960. The effect on milk yield of three times a day milking and of increasing the level of residual milk. J. Dairy Res. 28:209-219.

Farr, V. C., S. R. Davis, and K. Stelwagen. 1997. Removal of cisternal milk following milk accumulation for 9 hours does not increase total yield during once-daily milking. Proc. N.Z. Soc. Anim. Prod. $57: 217$.

Guinard-Flament, J., Y. Gallard, and H. Larroque. 2011. Lactose in blood plasma and the ability of dairy cows to tolerate once-daily milking in terms of milk loss and milk recovery. J. Dairy Sci. 94:3446-3454.

Hickson, R. E., N. Lopez-Villalobos, D. E. Dalley, D. A. Clark, and C. W. Holmes. 2006. Yields and persistency of lactation in Friesian and Jersey cows milked once a day. J. Dairy Sci. 89:2017-2024.

Kamote, H. I., C. W. Holmes, D. D. S. Mackenzie, R. J. Holdaway, and B. W. Wickham. 1994. Effect of once daily milking in later lacta- tion on cows with either low or high initial somatic cell counts Proc. N.Z. Soc. Anim. Prod. 54:285-287.

Kashyap, T. S., J. D. Donker, R. E. Comstock, and W. E. Petersen. 1967. Lactation studies. VII. Heritability of percentage of complementary milk. J. Dairy Sci. 50:722-724.

Kay, J. K., C. V. C. Phyn, A. G. Rius, S. R. Morgan, T. M. Grala, and J. R. Roche. 2013. Once-daily milking during a feed deficit decreases milk production but improves energy status in early lactating grazing dairy cows. J. Dairy Sci. 96:6274-6284.

Littlejohn, M. D., C. G. Walker, H. E. Ward, K. B. Lehnert, R. G. Snell, G. A. Verkerk, R. J. Spelman, D. A. Clark, and S. R. Davis. 2010. Effects of reduced frequency of milk removal on gene expression in the bovine mammary gland. Physiol. Genomics 41:21-32.

McPherson, A. W., J. E. Pryce, and A. M. Winkelman. 2007. The genetic improvement of cows for once-a-day (OAD) milking. Pages 44-48 in Proc. Once-a-Day Milking Conference, Hamilton, New Zealand. Dairy NZ, Hamilton, New Zealand.

Pomiès, D., B. Martin, Y. Chilliard, P. Pradel, and B. Rémond. 2007. Once-a-day milking of Holstein and Montbéliarde cows for $7 \mathrm{wk}$ in mid-lactation. Animal 1:1497-1505.

Rémond, B., and D. Pomiès. 2005. Once-daily milking of dairy cows: A review of recent French experiments. Anim. Res. 54:427-442.

Rémond, B., and D. Pomiès. 2007. Once-daily milking of Holstein cows for one-wk decreases milk yield by twenty-five percent without any carry-over effect. Livest. Sci. 110:192-195.

Rémond, B., D. Pomiès, D. Dupont, and Y. Chilliard. 2004. Once-daily milking of multiparous Holstein cows throughout the entire lactation; milk yield and composition, and nutritional status. Anim. Res. 53:201-212.

Spelman, R., F. Miller, J. Hooper, M. Thielen, and D. Garrick. 2001. Experimental design for QTL trial involving New Zealand Friesian and Jersey breeds. Proc. Assoc. Advmt. Anim. Breed. Genet 14:393-396.

Stelwagen, K. 2001. Effect of milking frequency on mammary functioning and shape of the lactation curve. J. Dairy Sci. 84:E204-E211.

Stelwagen, K., and S. J. Lacy-Hulbert. 1996. Effect of milking frequency on milk somatic cell count characteristics and mammary secretory cell damage in cows. Am. J. Vet. Res. 57:902-905.

Stelwagen, K., C. V. C. Phyn, S. R. Davis, J. Guinard-Flament, D. Pomiès, J. R. Roche, and J. K. Kay. 2013. Reduced milking frequency: Milk production and management implications. J. Dairy Sci. 96:3401-3413.

Turner, H. G. 1955. Sources of variation in residual milk and fat in dairy cows: Their relation to secretion rates and persistency of lactation. Aust. J. Agric. Res. 6:514-529.

Wall, E. H., and T. B. McFadden. 2012. A local affair: How the mammary gland adapts to changes in milking frequency. J. Anim. Sci. 90:1695-1707. 